\title{
The Art of Facilitating Archiving Workshops in South Africa, in Order to Develop Skills in the Archival Profession Accommodating Unique Challenges
}

\author{
PÉTRIA DE VAAL-SENEKAL, BA (HONS) CULTURAL HISTORY \\ De Vaal and De Vaal Information Brokers cc 174 President Steyn Street, Louis Trichardt, Limpopo Province, \\ South Africa \\ E-mail: petria@devaalanddevaal.co.za
}

The Art of Facilitating Archiving Workshops in South Africa, in Order to Develop Skills in the Archival Profession Accommodating Unique Challenges

\section{ABSTRACT}

The core of this article is aimed at highlighting the challenges in the facilitating of archiving workshops in South Africa. Apart from formal training of Archivists (of which some available qualifications and courses are discussed), there is a huge need for shorter, hands-on training. Learners represent a variety of working environments, backgrounds, levels of education, languages and cultures. The current situation in terms of formal training is briefly outlined. Available, more informal training and workshops are discussed as a means of filling the gaps for a specific sector in the archival profession. The challenges and the outline of workshops' content are shared. Current research in order to establish loopholes and needs regarding archival skills in the workplace, is mentioned. The majority of the article has been written against the background of the author's own experiences.

Key words: archival training, education, formal education, South Africa, professional qualification

L'arte di facilitare workshop archivistici in Sud Africa, allo scopo di sviluppare abilità nella professione archivistica per far fronte a sfide uniche

\section{ABSTRACT}

Scopo di questo articolo è evidenziare le sfide nell' agevolazione dei workshop archivistici in Sudafrica. Oltre alla formazione degli archivisti (di cui sono discusse alcune qualifiche e corsi disponibili), c'è un enorme bisogno di formazione più breve e pratica. I partecipanti rappresentano una varietà di ambienti di lavoro, di contesti, di livelli di istruzione, di lingue e di culture. Viene brevemente descritta l'attuale situazione in termini di formazione. Inoltre vengono discussi la formazione disponibile e più informale e i workshop intesi come mezzo per colmare le lacune di un settore specifico nella professione archivistica. Sono condivisi le sfide ed il contesto dei contenuti dei workshop. Ė menzionata la ricerca attuale per stabilire scappatoie e bisogni riguardanti le competenze archivistiche sul luogo di lavoro riferendosi soprattutto alle esperienze dell'autore.

Parole chiave: formazione archivistica, educazione formale, Sud Africa, qualifica professionale

Način izvajanja arhivskih delavnic v Južni Afriki z namenom razvijanja spretnosti v arhivskem poklicu z edinstvenimi izzivi

\section{IZVLEČEK}

Osrednji del tega člena je namenjen osvetlitvi izzivov pri izvajanju arhivskih delavnic v Južni Afriki. Poleg formalnega usposabljanja arhivistov (o katerem je govora tudi v članku), obstaja velika potreba po krajšem, praktičnem usposabljanju. Učenci prihajajo iz vrste različnih delovnih okolij, ozadij, stopenj izobrazbe, jezikov in kultur. V prispevku je na kratko predstavljeno trenutno stanje na področju formalnega usposabljanja. Razpoložljivo, bolj neformalno usposabljanje in delavnice so obravnavani kot sredstvo za zapolnjevanje vrzeli za posamezna področja $\mathrm{v}$ arhivskem poklicu. Predstavljeni so izzivi in osnutek vsebine delavnic, omenjene pa so tudi trenutne raziskave, na osnovi katerih bi bilo mogoče ugotoviti pomanjkljivosti in potrebe glede arhivskega znanja na delovnem mestu. Večina članka je napisana na osnovi lastnih izkušenj avtorice.

Ključne besede: arhivsko usposabljanje, izobraževanje, formalna izobrazba, Južna Afrika, poklicna kvalifikacija 
Pétria DE VAAL-SENEKAL: The Art of Facilitating Archiving Workshops in South Africa, in Order to Develop Skills in the Archival Profession Accommodating Unique Challenge, 23-31

\section{Introduction}

Archiving workshops are aimed at archivists or anyone working in an archive (especially those recently appointed); records managers or other records staff responsible for archiving (or those who are interested to know more); Museum staff who are responsible for their document collection / archiving; Library staff responsible for their document collection / archiving.

One often comes across staff members who have been thrown into the deep end. They might have a formal qualification, but little practical experience. Librarians, information workers, records staff, museum and heritage workers are not archivists, yet they have to look after their organisations' unpublished semi- or non-active documentary collections. It is expected from them to understand and practice the archival principles without necessarily having the correct skills and training.

The author's frame of reference is from the private as well as public sectors over a period of 30 years. The two different situations mentioned below, are representative of two formal qualifications. Please note that NOT all formal qualifications in South Africa are being discussed.

\section{The current situation in South Africa regarding formal training}

2.1 Further Education and Training Certificate: Archives and Records Management (SAQA - the South African Qualifications Authority) - ID 64069

The industry has suffered for a long time without any applicable unit standards and no qualification. (There were only the higher level qualifications offered by UNISA - see 2.2). In the beginning of 2009, an archiving and records management qualification was registered through SAQA on a NQF (National Qualifications Framework) Level 4.

According to Van Rooyen, no date, there was a need for a new education and training system in South Africa after the "apartheid" era. This was needed to enable the country to compete globally and to redress the inequities created by apartheid. The centre for Education Policy Development, The National Training Strategy Initiative and The ANC Education Desk made proposals towards a new system for South Africa during 1994 and three publications were produced. From these proposals it was clear that there should be an integration of education and training. The main instrument of integration was to be the national Qualifications Framework (NQF) and was created by means of three major Acts of Parliament. These Acts and Regulations are the following:

- South African Qualifications Authority Act (Act No. 58 of 1995)

- Skills Development Act (Act No. 97 of 1998)

- Skills Development Levies Act (Act No. 69 of 1999)

According to van Rooyen, no date, the NQF has the following purposes and was designed to:

- Promote easy access for learners;

- Recognise learning achievement through informal and formal means;

- Help people gain nationally recognised and portable (transferable) skills;

- Help identify capabilities needed to work;

- Help identify current skill gaps in order to develop training programmes;

- Provide an overview of capabilities needed in a profession;

- Provide employees with access to a career path;

- Provide better integration of on-the-job and off-the-job learning;

- Improve recognition of prior learning.

The purpose and rationale of this qualification, ID 64069 (SAQA, 2015) highlights South Africa's need of ensuring that records are kept for a range of purposes, is the primary purpose of the Records and Archives professionals, in a wide range of sectors. The Records and Archives profession continues to seek out new ways to meet the changing needs of identifying, retrieving, preserving and conserving information and items through well-structured record classification systems and record keeping systems, while at the same time dealing with significant changes in technology. 
In the records and archives environment, lifelong learning is crucial and practitioners must develop competencies for themselves for example analysing, acquiring, synthesising, organising, conserving, evaluating and disseminating records.

These competencies support, and are enhanced by, technological and social transformation. This qualification recognises all these elements in current and future records and archives practice. It aims to help people entering the industry and those already working in it maintain and improve their competencies in meeting and anticipating the needs of the country as a whole.

This Qualification enables learners within the Archives and Records Management environment to improve professionalism and enhance the quality of service delivery. It will also contribute to the further development of learners within the Archives and Records Management environment by providing articulation, recognition and mobility within this dynamic and ever changing environment.

A learner acquiring this Qualification will be able to:

- Communicate in a variety of ways in the provision of Records and Archives support services.

- Use mathematics and mathematical thinking to solve every day problems for him/herself and the Records and Archives profession.

- Manage archival materials and records.

- Provide routine frontline customer services for archives and records.

- Administer routine Records and Archives support services (SAQA, 2015).

An urgent need for the provision of training in the Archives and Records management sector is addressed by this qualification. Sound record keeping, archiving and records management practices are key elements of good governance and are also evidence of official and private business. They have an ongoing use as a means of legal evidence, operational continuity, and disaster recovery and are a means of accountability. This Qualification is for learners who are pursuing careers within the Archives and Records Management environment and indicates a clear learning pathway which can be followed. It provides learners with opportunities for professional development and career advancement within the broader constituencies of the administrative community that will contribute to providing better Archives and Records handling services for all the people in the Republic of South Africa.

This qualification reflects the need and demand within the Archives and Records Management environment for people who are/will be able to perform these administrative roles within surroundings which are more complex and demand more advanced knowledge, skills and attributes. This Qualification will provide a vehicle through which to develop competent Archives and Records Administrators and people that can stay abreast with the changing and dynamic environment of Archives and Records Management as well as create an atmosphere for life-long learning opportunities.

This qualification allows for the further development of learners in the Archives and Records Management' professional environment through vertical mobility to higher-level qualifications and horizontally to qualifications on the same level but in a different administrative discipline. The qualification assists learners in critically evaluating information and exercising appropriate professional judgement. The level of flexibility within the range of electives will also allow the individual to pursue further specialisation within the Archives and Records Management field (SAQA, 2015).

A Level 4 NQF is the equivalent of a Grade 12 or Matric.

Some of the advantages of this qualification are:

The focus of this qualification is on people who never had opportunities for qualifications before.

There were no unit standards whatsoever for Archiving and Records Management in South Africa.

Even if the qualification is not enrolled for, a learner can now demand alignment/accreditation to a unit standard of any training (short courses, workshops) in Archiving and Records Management.

It has become policy (especially in Government) to send learners on accredited training.

It builds bridges.

It fills gaps. 
Pétria DE VAAL-SENEKAL: The Art of Facilitating Archiving Workshops in South Africa, in Order to Develop Skills in the Archival Profession Accommodating Unique Challenge, 23-31

It paves the way for further education and training.

Gaps in the qualification can be reviewed regularly.

The learner can specialise in one of the following areas:

- Records Management

- Archives Management

- Public Sector

- Heritage

- Business Environment (SAQA 2015)

\subsection{University of South Africa (UNISA) Qualifications and opportunities}

UNISA offers a variety of opportunities.

There are three 4-5 day workshops available, namely the:

- Workshop in Basic Archives and Records Management;

- Workshop in Intermediate Archives and Records Management;

- Workshop in Advanced Archives and Records Management.

The one workshop follows on the other. Any Level 4 qualification OR at least two years' work experience in a records centre, archives or registry is required. (http://brochure.unisa.ac.za)

\section{Programme in Archival Studies}

Most archivists in South Africa qualify by means of this course.

\section{Purpose}

This programme is offered to candidates in possession of any degree or any other national diploma. After completing the programme, students receive a certificate and may progress to the Honours Bachelor of Arts in Archival Science at UNISA.

\section{Target group}

Any person with a National Diploma or Degree interested in archives and records management.

\section{Admission requirements}

Candidates in possession of any degree or any other national diploma.

\section{Duration}

One year full time or two years part-time.

\section{Language medium}

English.

\section{Tuition method}

This course is offered by means of distance teaching with the assistance of study guides, prescribed books and readers, while lecturers are available through telephone contact and e-mail. Course work is organised by means of tutorial letters. Assessment includes assignments and examinations. The exams for each module are held at the end of the year.

Kind of assessment

Note:

Formative assessment and examination admission will comply with UNISA's formative assessment rules and policies

Formative assessment:

Written assignments and self-assessment activities 
Pétria DE VAAL-SENEKAL: The Art of Facilitating Archiving Workshops in South Africa, in Order to Develop Skills in the Archival Profession Accommodating Unique Challenge, 23-31

\section{Summative assessment:}

Examinations and portfolio of evidence of experiential training received at the approved archives and/or records centre)

\section{Marks:}

Students will have to obtain a mark of $50 \%$ to successfully complete the course

The different modules in this course are:

Module 1. Introduction to Records Management and Archival Studies

\section{Syllabus/Content Topics}

This module forms the basis of the course in Archival Studies. It contains the basic information needed to familiarise oneself with archives. Some of the principles introduced here are discussed in detail in other modules. This module can be regarded as a framework for Archives and Records Management. The text has been compiled with the aim of helping the student to master the content of this course as easily as possible. This course therefore aims to give the student, a prospective archivist, the theoretical information and practical skills needed for executing tasks in archives effectively.

\section{Module 2. Archival Principles and Practices}

\section{Syllabus/Content Topics}

- This module aims to provide a frame of reference for the development of the theory of systems of arrangement and classification.

- Practical guidelines are given concerning the arrangement of paper-based archives and collections. The different stages of sorting are explained so that they can be applied in practice. Arrangement and intellectual control by means of description are explained with regard to audio-visual material, which includes cinematographic material, video material, sound material (such as gramophone records, compact discs and audiotapes) and digital recordings. Finding aids, with special reference to the inventory and the catalogue and their defined structures in archives, are also set out.

- Not all records can be preserved because of insufficient storage space. In order to establish which records have value and should be preserved and which records should be regarded as ephemeral, efficient records management systems have been developed as a tool for this purpose. Records management and its implementations and value in the business sector are detailed. The major methods used and the steps taken with regard to the compilation of records inventories and the disposal of records are explained in the section on records management. Modern or present-day requirements regarding the inventory of electronic records are also examined. The last unit of this module focuses on the arrangement of official records as prescribed by legislation and implemented by the National Archives of South Africa.

\section{Module 3. Archival Information Sources and Services}

\section{Syllabus/Content Topics}

- The module for Archival Information Sources and Services covers a wide range of topics which are of interest to prospective records managers and archivists. It includes information on the various types of archives services offered in South Africa and the rest of the world, and the types of information sources that can be found within these archives. To better understand these archives, this guide also provides the student with the reasons these archives were established.

- The legal environment in which archives operate is also discussed.

\section{Module 4. Preservation and Conservation of Archival Materials}

\section{Syllabus/Content Topics}

- This module deals with some of the most fundamental aspects of archival studies and of archives. If there were no need for the communication of information from the past to the future, it 
would not be necessary to record externalised knowledge, or to invent a social agency to collect evidence of transactions, make them accessible to users and preserve them. Without this social need of remembering the past, archives would never have existed in contemporary or past societies.

- This module has been compiled with the aim of introducing the student to the various types of archival records, their characteristics, and potential use by archives and preservation (http:// brochure.unisa.ac.za)

Note: $\mathrm{Al}$ the above address courses that include records management AND archiving.

\section{The current situation in South Africa regarding informal training}

The term: "informal" is possibly not correct, but it is a way of describing a method of training used in South Africa. This is usually done in workshop format, seminars, or discussion groups. Training like this should preferably be accredited according to Unit Standards within a qualification like the "Further education and Training Certificate: Archives and Records Management, ID 64069 (SAQA, 2015).

\subsection{Accreditation}

Accreditation processes are in certain instances lengthy and complicated. In the meantime, there are many prospective learners who are in urgent need of training. There is not always time to wait for accredited courses. Accredited training can also be costly.

A challenge in South Africa is that some service providers manage to get accredited, sometimes at a cost, but they do not have the know-how in order to facilitate. Knowledgeable facilitators are sometimes hired in, or, in a worst case scenario, a facilitator without the required skills, qualifications or experience, are used to facilitate within a profession like archiving. Many learners (and their employers) complain afterwards that they expected more from these accredited courses.

When this happens, they often look for a facilitator who is knowledgeable, irrespective of the fact that he or she offers so-called "workshops" instead of accredited training. Accreditation is, however, a requirement within many organisations. This results in the situation where facilitators are knowledgeable and experienced, but cannot manage to get accredited. On the other hand, you have training companies and/or facilitators who get accredited, but are not knowledgeable enough ${ }^{1}$.

\subsection{Who requires archive training?}

On many occasions, staff members within an archive environment, are identified who need training. These learners often request "on-site" training, upon which a facilitator go to the organisation and facilitate the workshop. These workshops can be between 3 and 5 days, depending on what they need to learn or be exposed to. Follow-up, more advanced workshops, can also be offered.

On the other hand, workshops are arranged for any interested parties. A variety of learners respond to advertisements. They could be librarians, information workers, records staff, museum and heritage workers or even already qualified archivists who need more information in a specific area, or who need a refresher on certain aspects of archiving.

\subsection{Challenges for the facilitator in the archival training classroom ${ }^{2}$}

The facilitator in South Africa is faced with a variety of challenges. These include the following:

- Learners represent a variety of working environments. An archivist working in an art gallery, will deal with a different type of record than the one working in a bank archive, a museum archive or a music archive.

- Different backgrounds and levels of education also have an influence on the approach followed

1. Based on the experience of the author and informal discussions with colleagues in the fields of records management in South Africa.

2. This is based on a 20-year-experience of the author and is not referenced to in any other consulted source. 
by the facilitator. Sometimes, there are learners who only have a limited level of literacy, e.g. a clerk who helps as an assistant in an archive. Others are in high level positions e.g. managers. It is a challenge to accommodate both of these representatives and to ensure that they both walk away fully equipped to implement what they have learnt in the workplace.

- Language can be a challenge. There are 11 official languages in South Africa. The most common "working" language is English. For the majority of people, English is a second or even a third language. A facilitator whose first language is English, may talk on a level where the learners not necessarily understand all terminology and concepts. It has been established that a facilitator whose second language is English, communicate better with the learners in the same position.

- Language in terms of the content of archives is also a challenge. A learner may be working in an archive where some records are still in Dutch. Afrikaans, the language that developed mainly from Dutch, was only recognised as from 1875. Learners are not necessarily familiar with Dutch. Many learners are not even familiar with Afrikaans, as it is a minority group in South Africa.

- The variety of cultures represented in South Africa makes the facilitation process unique. All cultures need to be understood and accommodated. Although religion and politics are not discussed in the classroom environment, it is sometimes necessary to understand where a learner comes from and what his or her viewpoints are. $\mathrm{He} /$ she might also represent a specific archive, e.g. the ANC Archives (political party), a Church Archive, The "Apartheid" Museum, etc. There may be representatives of all of these learners in the same learning environment. The facilitator needs special skills in how to address possible conversations between learners or specific content from an archive that is mentioned as an example in the classroom.

- For some learners it is a first time to receive training. A complex situation may develop in terms of him or her being withdrawn or too shy to participate. The facilitator has to have enough knowledge of personalities and circumstances in order to accommodate this learner and to make him/her part of the class.

- The number of delegates should be limited to a maximum of 15. Any number more than this, is a challenge for the facilitator, as individual needs should be expressed within the classroom environment and enough time should be available for discussion in this regard.

- It is a challenge to create a comfortable learning environment for everybody in which he/she does not only learn, but have enough time to do hands-on practical work that enables them to take back the knowledge and ideas to the workplace and implement such immediately. Too many, more "formal" training is not hands-on in a short period of time.

- Cost of training is always a challenge. Longer, more formal courses can be costly. Shorter workshops or seminars are also offered at a cost, but the results are immediate. An employer can experience his invested money shortly after the learner attended the workshop/seminar.

- Learners (often from one organisation) sometimes require training on a specific aspect of archival functions, e.g. arrangement and description. This can be offered - mainly in-house training. The success rate of actual work that gets done after the training, is very high. Follows-up is usually done and the facilitator can make an arrangement to "hold the hands" of the client for an arranged period of time after completion of the training.

\subsection{The outcome of the workshop}

Learners want to equip themselves and to develop their skills. This is the outcome that they can expect in the more "informal" workshops:

At the end of the workshop candidates will be in the position to identify archival records, to add value and appraise accordingly, to take care of the records physically (correct shelving, boxing, covering, protect against disasters, etc.) sort, arrange and describe records in order to retrieve them easily, know the obligations of legislation and be able to implement all the requirements, e.g. a disaster recovery plan. Learners will be able to do emergency reparations on documents (DeVaal-Senekal, 2016).

Learners will be able to show responsibility, and independently and effectively manage themselves in the specific culture of the Archives environment and they will therefore ensure the effective delivery of relevant and appropriate Archive services within the framework of prescribed legislation $(S A Q A, 2015)$.

All of this is, however, done in a very practical, hands-on manner. Learners enjoy the interaction not only with the facilitator, but also with each other. 
Pétria DE VAAL-SENEKAL: The Art of Facilitating Archiving Workshops in South Africa, in Order to Develop Skills in the Archival Profession Accommodating Unique Challenge, 23-31

\subsection{The way forward}

Current research is undertaken by the author in order to establish more loopholes and needs with regard to archival skills in the workplace. This is done by means of "knowledge mapping". The results guide the facilitator towards specific needs and challenges in the archival environment within all types of organisations - public as well as private sector.

Davenport and Prusack (1989) explain that 'working knowledge' ads on to the intellectual capital of the organisation. Intellectual capital again forms the degree of competitive advantage against other organisations operating in the same field.

\section{Advantages of knowledge mapping in an archive environment:}

- Knowledge mapping helps to clearly identify what knowledge is needed to support goals and individual and team activities.

- It explains how knowledge moves around in, and is used by the archive / organisation.

- It provides a map of what knowledge exists in the archive and where it exists, revealing both gaps and duplication.

- It provides an inventory of knowledge assets, allowing them to become more visible and therefore more measurable and accountable. It gives tangible evidence of the extent to which knowledge is effectively managed and indicates where improvements are needed.

- It provides vital information for the development of effective knowledge management programmes and initiatives that are directly relevant to the archives' specific knowledge needs and current situation.

With these results in hand, improved workshops can be offered for learners in the archival environment. An important aspect that has been discovered so far, is the fact that many employees can undergo a process of "recognition of prior learning - RPL". Those staff members working in a specific environment for years, but never had the opportunity to undergo any training, can now be evaluated and can obtain some qualification.

\section{Conclusion}

Formal, accredited training is always recommended. However, bearing in mind all the challenges mentioned, there is a place for non-accredited training, as long as the content of these workshops are of a high standard and quality. During these training sessions, the facilitator should always ensure that not only theoretical knowledge is shared, but that learners have the maximum benefit of this type of learning environment.

Certificates of attendance are usually issued after the workshop. The facilitators in this position find themselves constantly in situations where they have to motivate that their workshops are of such a nature that learners learn what they need to learn and that skills are developed just as well as in similar accredited training.

To accomplish the accreditation process in South Africa, will always be a challenge. It should always be a goal to get accreditation, but in the meantime, no time should be wasted and knowledgeable facilitators should transfer skills to eager learners - usually a younger generation.

\section{References}

Davenport, T \& Prusack, L. (1998). Working knowledge: How organisations manage what they know. Boston: Harvard Business School Press

De Vaal-Senekal, P. (2016). The Comprehensive Archiving Workshop (revised). Pretoria

SAQA (2015), Qualification 64069, NQF Level 4: Further Education and Training Certificate: Archives and Records Management (re-registered), Pretoria: SAQA

UNISA: Short learning programmes, brochure. Available at http://brochure.unisa.ac.za (accessed on 13.04.2017) Van Rooyen, M. (no date). Conduct Outcomes-based Assessment. Johannesburg: Assessment College of South Africa 
Pétria DE VAAL-SENEKAL: The Art of Facilitating Archiving Workshops in South Africa, in Order to Develop Skills in the Archival Profession Accommodating Unique Challenge, 23-31

\section{SUMMARY}

Formal (mainly accredited) training is available in South Africa. The institution who trains most archivists is UNISA (University of South Africa). Accreditation of training courses are lengthy and sometimes complicated. In the meantime, there is a huge need for hands-on, practical training within a short period of time for archivists and staff from related disciplines, e.g. the library environment, museums, records management, etc. Employers demand immediate implementation of knowledge obtained at a workshop. They feel that they get value for money. Most organisations, however, still demand accredited courses. There is "informal" training available in the form of mainly workshops or seminars. The author has been involved in this type of training for more than 20 years and shares her experiences in terms of challenges and the accommodation thereof. Unique situations are common when having representatives from different cultures, background, educational level, religion, political viewpoints and of course different types of archives. It became an art to accommodate all the challenges. The facilitator needs to be a creative person - not only knowledgeable in the content trained, but also in inter-personal relationships, knowledge about a learner's unique situation, etc. Over a period of 20 years, the approach in the classroom is one of not only learning, but accommodating all challenges in a respectful manner. Constant research is done in order to improve learning and facilitating - therefore research in terms of knowledge mapping is currently undertaken in a variety of organisations with their own unique archives and accompanying acquisition policies. The results thereof are being used for future development of course material and specifically addressing the needs of the learners. To accomplish the accreditation process in South Africa, will always be a challenge. It should always be a goal to get accreditation, but in the meantime, no time should be wasted and knowledgeable facilitators should transfer skills to eager learners - Usually a younger generation.

Typology: 1.04 Professional Article

Submitting date: 18.04 .2017

Acceptance date: 05.05 .2017 